\title{
Microbiological, physicochemical, and organoleptic evaluation of fresh-cut vegetables irradiated using $X$-rays
}

\author{
Byeong-Geum Moon ${ }^{1,3 *}$, Beom-Seok Song ${ }^{1}$, Jong-Heum Park ${ }^{1}$, Jae-Kyung Kim ${ }^{1}$, \\ Ha-Young Park ${ }^{1}$, Dong-Ho Kim ${ }^{1}$, Eun-Joo Son ${ }^{2}$, Don-Sun Im ${ }^{1}$, Jong-Bang Eun ${ }^{3}$ \\ ${ }^{1}$ Department of biotechnology, Advanced Radiation Technology Institute, Korea Atomic Energy Research Institute, \\ Jeongeup 56212, Korea \\ ${ }^{2}$ Department of Nutrition Care, Dongnam Institute of Radiological and Medical Science, Busan 46033, Korea \\ ${ }^{3}$ Department of Food Science and Technology, Chonnam National University, Gwangju 61186, Korea
}

\section{엑스선 조사처리된 신선편의 채소류의 미생물학적, 이화학적, 관능적 품질 평가}

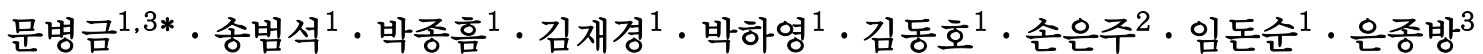 \\ ${ }^{1}$ 한국원자력연구원 첨단방사선연구소 생명공학연구부, ${ }^{2}$ 동남권원자력의학원 영양실, ${ }^{3}$ 전남대학교 식품공학과
}

\begin{abstract}
Microbiological, physicochemical, and organoleptic properties of fresh-cut vegetables (FVs), carrots, green peppers, cherry tomatoes, and paprika after $X$-ray irradiation were evaluated to verify food quality suitable for the immune-depressed patients. Total concentrations of aerobic bacteria in non-irradiated samples, except for chenry tomatoes, were 1.63-3.34 log CFU/g. Irradiation dose exceed 0.4 kGy was used for carrots and green peppers whereas the sterilization dose of $0.2 \mathrm{kGy}$ was used for both cherry tomatoes and paprika. A dose of $0.4 \mathrm{kGy}$ was tentatively determined as the minimum allowable dose for sterilization of the FVs, based on $D_{10}$-values of X-ray irradiation (0.11-0.32 kGy) for Escherichia coli, Listeria monocytogenes, and Salmonella Typhimurium inoculated on the samples. With respect to the physiological properties, only hardness was significantly decreased as the absorbed dose increased; however, there were no significant differences in hardness of the sterilized samples using X-rays at $0.4 \mathrm{kGy}$ compared with those of non-irradiated samples $(\mathbf{p}<0.05)$. Moreover, overall acceptance scores of the sterilized FVs were higher than 5.0 points on a 7-point scale, indicating a good organoleptic quality. In a survey on preference of hospitalized patients with cancer $(n=50)$, the average scores for the sterilized FVs, except for carrots, were higher than 4.0 points. In conclusion, it is considered that the FVs, except for carrots, sterilized using X-rays at $0.4 \mathrm{kGy}$ could be served to immune-depressed patients as hygienically safe foods with acceptable organoleptic properties.
\end{abstract}

Key words : X-ray, fresh-cut vegetable, quality, immune-depressed patient, $D_{10}$-value

\section{서 론}

현재 우리나라에서는 진단기술의 발달과 노인 인구의 증가 추세에 따라 암 환자의 수가 갈수록 증가하고 있다(1).

*Corresponding author. E-mail : mbg@kaeri.re.kr Phone : 82-63-570-3217, Fax : 82-63-570-3207

Received 7 November 2016; Revised 13 January 2017; Accepted 25 January 2017.

Copyright (c) The Korean Society of Food Preservation. All rights reserved.
암환자에 있어서 영양 불량 상태는 암의 치료를 방해하며, 사망률과 이환율을 증가시키는 원인이 되므로 다양한 식품 섭취와 적절한 영양섭취가 필요하다(2). 그러나 항암화학 요법, 방사선요법 등의 치료과정 중 저하된 면역력과 식욕 부진으로 인해 이들이 섭취할 수 있는 식품의 품목은 제한 적이다. 면역력이 약해진 환자가 비멸균 제품을 섭취할 경 우 세균에 의한 장관내의 감염으로 합병증을 일으킬 가능성 이 일반인에 비해 크기 때문이다(3).

최근 경제 성장과 더불어 식생활 수준이 향상되어 신선 편의 채소류와 같이 세척, 박피, 절단 등 최소 가공으로 
주원료 그대로 섭취할 수 있는 식품이 국내 시장에서도 다양하게 판매되고 있으며, 지속적으로 소비가 증가하고 있다(4,5). 그러나 신선편의 채소류의 경우 세척 등의 단순 위생 공정을 거치므로 토양으로부터 유래된 식중독균에 노출이 쉬우며, 작업자에 의한 2 차 오염 또는 식품 간 교차 오염으로 인해 위생학적 안전성이 낮아질 수 있다. 따라서 이들 채소류의 고유의 맛과 조직감을 유지하면서도 위생학 적 안전성을 확보할 수 있는 위생화 기술의 적용이 필요한 실정이다.

미국의 경우 1990-2001년 동안 신선 채소 등의 오염으로 인한 식중독 사고는 총 148 건이며, 모든 식중독 사고 중 $9 \%$ 에 해당된다고 하였다(6). 또한, 건강에 대한 관심의 증 가로 샐러드 등 다양한 채소를 생식하는 일이 많아졌고 새싹 채소, 양상추 등의 신선 채소와 관련된 식중독 사고도 적지 않게 발생되고 있다(7,8). 국제기구(FAO/IAEA/WHO) 에서 방사선 조사기술의 건전성과 경제성이 공인되어 약 230 여종의 식품에 대하여 식품 방사선 조사를 허가하고 있다. 방사선 조사 기술은 대표적인 비가열 살균 기술로써 식품 고유의 관능적 품질 유지가 가능하고 제품을 포장한 상태에서 조사처리가 가능하여 살균처리 후 재포장에 따른 2차 오염을 방지할 수 있다(9-11). 특히 엑스선은 식품 조사 처리에 사용 가능한 이온화 방사선의 하나로써 감마선과 같은 전자기파이며 이와 유사한 투과력을 나타낸다. 엑스 선을 포함하여 감마선과 전자선의 살균 효과를 비교한 결 과, $7.5 \mathrm{MeV}$ 엑스선 조사는 감마선, 전자선과 유사한 살균 효과를 나타내었다(12). 또한, 엑스선 발생장치는 소형화가 가능하고 자체적으로 차폐가 가능하며, 사용조작이 간단하 므로 운용적 측면에서 많은 장점을 가지고 있다(13). 현재 엑스선은 포장된 완제품 내의 이물 검사 등의 목적으로 식품 분야에서 활용되고 있으며, 아직까지는 국내에서 엑 스선을 이용한 식품 조사처리가 허가되어 있지 않다. 그러 나 엑스선 발생장치 개발 기술의 발전으로 식품의 살균/살 충을 위한 목적으로써 앞으로의 사용 확대가 기대되며, 엑 스선을 다양한 품목에 이용하여 소비자들에게 미생물학적 으로 안전하고 관능적 품질 저하가 나타나지 않은 수준의 적정 선량을 알아보기 위한 연구가 필요하다.

따라서 본 연구는 당근, 오이고추, 방울토마토 및 파프리 카를 신선편의 채소류의 모델식품으로 선정하여 다양한 흡수선량으로 엑스선 조사처리 후 미생물학적, 이화학적, 관능적 품질 특성을 평가하였다. 엑스선을 이용한 조사 효 과와 생채소류 및 샐러드류에 대한 요구도가 높은 면역력 저하 환자에게 멸균식으로써 신선편의 식품의 적용 가능성 을 살펴보았다. 아울러 동남권원자력의학원에 입원 중인 암환자를 대상으로 선호도 설문 조사를 진행함으로써 실현 가능성을 확대하였다.

\section{재료 및 방법}

재 료

본 실험에 시료로 사용된 당근, 오이고추, 방울토마토, 파프리카는 전라북도 정읍시 인근 마트에서 구입하였으며, 흐르는 물에 세척 후 박피 및 절단하여 $10 \mathrm{~g}$ 씩 포장용기에 포장하여 구입 후 당일에 실험에 사용하였다.

\section{엑스선 조사}

시료의 엑스선 조사처리는 low energy X-ray 발생장치 (Cabinet X-ray system CP-160, Faxitron X-ray LLC., Lincolnshire, IL, USA)를 이용하여 $160 \mathrm{kV}, 10 \mathrm{~mA}$ 의 beam current 조건하에서 $0.2,0.4,0.6 \mathrm{kGy}$ 의 흡수선량이 되도록 시간을 달리하여 조사처리하였다. 시료의 흡수선량은 조사 처리 전 포장용기 내부에 삽입한 alanine dosimeter(Bruker BioSpin $\mathrm{GmbH}$, Rheinstetten, Germany)를 electron paramagnetic resonance analyzer(e-scanTM alanine dosimeter reader, Bruker BioSpin $\mathrm{GmbH}$ )로 분석하였으며, 이 dosimetry 시스템은 국제원자력기구의 절차에 따라 표준화 한 후 사용하였다. 측정된 흡수선량의 불확도는 신뢰구간 95\% 수준으로 $5 \%$ 이내였다.

\section{미생물 오염 수준 평가}

시료의 미생물 오염수준을 확인하기 위하여 총 호기성세 균, 진균류, 대장균군, Escherichia coli, Salmonella spp., Bacillus cereus, Staphylococcus aureus, Clostridium perfringens 의 생균수를 측정하였다. 즉, 시료 $10 \mathrm{~g}$ 에 멸균된 peptone수 $90 \mathrm{~g}$ 을 가하여 1 분간 stomacher(Mark II Lab Blender, Tekmar Teledyne Technologies Inc., Sacramento, CA, USA) 를 이용하여 균질화한 후 10 진 희석법으로 희석한 현탁액 을 실험에 사용하였다. 각각의 미생물에 대하여 사용된 배 지의 경우 총 호기성세균은 plate count agar(PCA, Difco Co., Detroit, MI, USA), 진균류는 potato dextrose agar(PDA, Difco Co.), 대장균군은 eosin methylene blue agar(EMB, Difco Co.), E. coli는 3M petrifilm(St. Paul, MN, USA), B. cereus 는 mannitol egg yolk polymyxin agar(MYP, Difco Co.), S. aureus 는 Baird-Parker Agar(BPA, Difco Co.), Salmonella spp.는 Salmonella Shigella agar(SSA, Difco Co.), C. perfringens는 tryptose sulfite cycloserine agar(TSC, Oxoid, Hampshire, England)를 사용하였다. 희석된 시료 현 탁액 $0.1 \mathrm{~mL}$ 를 plate에 각각 도말한 후 $\mathrm{PCA}, \mathrm{EMB}, \mathrm{MYP}$, $\mathrm{BPA}, \mathrm{SSA}$ 배지는 $35^{\circ} \mathrm{C}$ 에서 24-48시간, TSC 배지는 anaerobic jar(Oxoid, Hampshire, England)를 이용하여 혐기 적 조건에서 $35^{\circ} \mathrm{C}$ 에서 $24-48$ 시간, $\mathrm{PDA}$ 배지는 $25^{\circ} \mathrm{C}$ 에서 72시간 각각 배양하여 30-300개의 집락을 형성한 배지만을 계수하였다. 또한, 시료 $1 \mathrm{~mL}$ 를 분주한 도말된 건조필름 배지는 $35^{\circ}$ C에서 $24-48$ 간 배양하여 기포를 가진 blue colony 
를 형성한 집락수를 계산하였다.

시료의 멸균 여부를 확인하기 위해 식품공전의 세균발육 시험법(KFDA, 2012)을 이용하였다. 즉, 시료를 무균적으로 $10 \mathrm{~g}$ 을 취한 후 멸균 PBS buffer solution $90 \mathrm{~mL}$ 를 가하고, 20 초간 vortexing 하였다. 이 용액의 $1.0 \mathrm{~mL}$ 에 멸균된 thioglycollate medium(Sigma-Aldrich co., St. Louis, MO, USA) $9.0 \mathrm{~mL}$ 을 가하고, $35^{\circ} \mathrm{C}$ 의 incubator(MIR-262, Sanyo, Tokyo, Japan)에서 48시간 동안 배양시켜 yellow 계통으로 변색되지 않는 것을 멸균된 것으로 확인하였다.

\section{병원균 접종 실험}

미생물보존센터에서 Sallmonella Typhimurium(KCTC 1925), E. coli(KCCM 11234), L. monocytogenes(KCCM 40307) 균주를 분양 받은 후 tryptic soy broth(TSB, Difco Co.) $100 \mathrm{~mL}$ 에 균주 $100 \mu \mathrm{L}$ 를 접종하여 각각 6시간, 7시간, 15 시간 진탕배양하여 대수기 상태의 균체를 얻었다. 이후 $50 \mathrm{~mL}$ falcon tube에 $30 \mathrm{~mL}$ 씩 분주한 후 원심분리기를 이용 하여 $3,000 \mathrm{rpm}, 10^{\circ} \mathrm{C}, 10$ 분 동안 원심분리 하였다. 모아진 균체를 제외하고 상층액을 제거한 후 PBS buffer $30 \mathrm{~mL}$ 을 각각의 tube에 분주하였다. 분주된 tube를 vortexing과 원심 분리(3,000 rpm, $10^{\circ} \mathrm{C}, 10$ 분간)를 하여 clean up 작업을 수행 하였다. 이 과정을 3회 반복하여 모아진 균체를 $10^{9}$ 에서 $10^{10}$ 농도로 하여 현탁액으로 사용하였다.

접종실험 하루 전에 $30 \mathrm{kGy}$ 의 흡수선량으로 감마선 멸균 처리된 $10 \mathrm{~g}$ 의 시료에 3종의 세균 현탁액 $100 \mu \mathrm{L}$ 를 각각 clean bench에서 무균적으로 접종하였으며 100 분간 자연건 조 하였다. 이후 sealing하여 당일에 바로 다양한 흡수선량 으로 엑스선 조사처리를 하였다. 조사처리 후 시료 $10 \mathrm{~g}$ 에 $0.1 \%$ 멸균펩톤수(Difco Co.)를 멸균된 filterbag에 넣고, stomacher lap blender(Mark П Lap Blender, Tekmar Teledyne Technologies Inc., Boston, MA, USA)에서 1분간 균질화한 후, 단계별 희석하여 Tryptic Soy Agar(Difco Co.) 에 도말하였다. 도말된 평판들은 $35^{\circ} \mathrm{C}, 48$ 시간 배양하여 집락을 형성한 배지만 선택하여 계수 하였고 시료 $1 \mathrm{~g}$ 당 colony forming unit(CFU)로 나타내었다. 미생물 검출 한계 치는 $1 \log \mathrm{CFU} / \mathrm{g}$ 이었다.

접종 실험을 통한 미생물 3 종의 $\mathrm{D}_{10}$ 값은 방사선 감수성 을 표시하는 것으로 미생물의 개체수를 $1 / 10$ 로 줄이는데 필요한 방사선 선량을 D10-value로 하여 그 감수성과 저항 성을 표시하였다.

\section{이화학적, 관능적 품질 평가}

$\mathrm{pH}$ 는 시료 $10 \mathrm{~g}$ 에 멸균 증류수 $90 \mathrm{~mL}$ 를 가하여 homogenizer(DIAX 900, Heidolph Co., Berlin, Germany)로 $20,000 \mathrm{rpm}$ 으로 1 분간 균질화 하였다. 이후 토마토를 제외 한 시료는 $10^{\circ} \mathrm{C}$ 에서 10 분간 $3,000 \mathrm{rpm}$ 으로 원심분리 시켰 으며, 토마토는 $5^{\circ} \mathrm{C}$ 에서 10 분간 $5,000 \mathrm{rpm}$ 으로 원심분리
시켰다. 그 상등액을 여과지(Whatman No. 4, Maidstine, England)로 여과하여 pH-meter(Orion 520A, Orion Research Inc.)를 사용하여 6회 반복 측정하여 평균값으로 나타냈다. 적정산도는 여과액을 $0.1 \mathrm{~N} \mathrm{NaOH}$ 용액으로 $\mathrm{pH}$ 가 8.3이 되도록 적정하여 중화시키는데 소비된 $\mathrm{NaOH}$ 소비량 $(\mathrm{mL})$ 을 측정한 후 당근은 0.0067 (malic acid), 오이고추와 파프리 카는 0.006(acetic acid), 방울토마토는 0.0064(citric acid)로 환산하여 총산 함량(\%)을 표시하였으며, 적정산도 실험은 6회 반복 측정 후 평균값으로 나타내었다.

색도는 시료 단면을 색도계(Chroma Meter, CM-5, Konika Minolta Inc., Marunouchi, Japan)를 이용하였으며, 명도 (lightess, L), 적색도(redness, a), 황색도(yellowness, b)를 측 정하였다. 경도는 Texture Analyzer(TA-XY2i, Stable Micro System Co., Surrey, England)를 이용하였으며, 시료의 경도 (firmness)를 측정하였다. Cylinder type probe $(5 \mathrm{~mm}$ diameter)를 사용하여 상온에서 측정하였고 분석조건은 pre-test speed $5.0 \mathrm{~mm} / \mathrm{s}$, test speed $5.0 \mathrm{~mm} / \mathrm{s}$, post-test speed $5.0 \mathrm{~mm} / \mathrm{s}$, distance $50.0 \%$ 으로 설정하였다.

시료의 관능평가는 관련분야를 전공한 연구원 패널 8 명 을 대상으로 7점 척도법을 이용하여 기호도 및 특성강도 검사를 실시하였다. 평가항목은 기호도 검사로 외관 (appearance), 풍미(flavor), 조직감(texture), 맛(taste) 및 종합 적 기호도(overall acceptance)를 평가하였으며 특성강도 검 사는 이취(off-flavor)에 대하여 실시하였다. 패널에게 관능 검사 중 나이, 성별 등을 기록하고 물과 시료를 뱉는 컵을 시료 사이에 제공하였으며, 검사 중의 영향을 최소화하기 위해 총 소요시간은 10-20분으로 정하였다.

\section{암환자 대상 설문조사}

동남권원자력의학원에 입원 중인 환자 50 명을 대상으로 엑스선 조사처리 $(0.4 \mathrm{kGy})$ 를 통해 멸균 처리한 신선편의 채소류에 대한 선호도 설문조사를 실시하였다(동남권원자 력의학원 임상연구심의의원회 No. D-1511-002-002). 입원 환자용 급식 식단에 멸균 처리된 신선편의 채소류를 첨가하 여 조식, 중식, 석식 3회로 나누어 배식 하였다. 대상 환자군 에게 연구목적 및 방법을 설명하고 설문동의서를 받은 뒤 시식 후 5점 척도(매우 나쁘다, 1 ; 나쁘다, 2 ; 보통이다, 3 ; 좋다, 4 ; 매우 좋다, 5)로 분류하여 설문지에 응답하도록 하였다.

\section{통계처리}

모든 측정 결과는 평균값 \pm 표준편차로 나타내었으며, Statistical Package for the Society Science(SPSS, windows ver 21.0, SPSS IBM., Chicago, IL, USA)을 이용하였다. 각 시료간의 유의성을 검증한 후 $\mathrm{p}<0.05$ 수준에서 Duncan's multiple range test로 사후검정을 실시하였다. 


\section{결과 및 고찰}

\section{신선편의 채소류의 미생물학적 품질 평가}

신선편의 채소류를 다양한 흡수선량 $(0.0-0.6 \mathrm{kGy})$ 으로 엑스선 조사처리한 후 생균수를 측정한 결과를 Table 1에 나타내었다. 비조사처리 당근의 경우 총 호기성세균이 2.27 $\log \mathrm{CFU} / \mathrm{g}$ 이었고 $0.2 \mathrm{kGy}$ 의 흡수선량으로 조사처리하였을 때 $1.00 \log \mathrm{CFU} / \mathrm{g}$ 으로 약 $1 \log$ 수준이 감소되었다. 따라서, 총 호기성세균의 경우 $0.4 \mathrm{kGy}$ 조사처리 시료에서는 검출 한계(1 $\log \mathrm{CFU} / \mathrm{g})$ 이하로 나타났다. 비조사구에서 대장균 군이 $1.15 \log \mathrm{CFU} / \mathrm{g}$ 이었으나 $0.2 \mathrm{kGy}$ 로 조사처리 시 검출 한계 이하로 확인되었다. 총 호기성세균과 대장균군을 제 외한 E. coli, Salmonella spp., B. cereus, S. aureus, $C$. perfringens는 비조사구와 모든 조사구에서 검출되지 않았 으며, 세균발육시험을 통한 멸균 여부 확인 평가 결과 0.4 $\mathrm{kGy}$ 이상의 흡수선량으로 처리한 실험구들은 멸균이 된 것으로 확인되었다. 오이고추의 경우 비조사 처리구에서 각각 3.34, $2.68 \log \mathrm{CFU} / \mathrm{g}$ 의 총 호기성세균과 대장균군이 검출되어 시험에 사용된 시료들 중 가장 높은 오염수준을 나타내었다. 그 밖의 세균들은 당근의 경우와 같이 모두 검출한계 이하로 나타났으며, $0.4 \mathrm{kGy}$ 이상의 흡수선량으 로 처리한 실험구들은 멸균되었다. 방울토마토와 파프리카 의 경우 당근과 오이고추에 비해 미생물 오염수준이 낮았으 며, 모두 $0.2 \mathrm{kGy}$ 의 흡수선량 이상으로 엑스선 조사처리
시 세균의 발육이 없는 것으로 나타났다. 이상의 결과를 토대로 신선편의 당근, 오이고추, 방울토마토, 파프리카는 모두 $0.4 \mathrm{kGy}$ 이하의 흡수선량으로 엑스선 조사처리 시 멸균이 가능한 것으로 판단하였다.

\section{신선편의 채소류에 접종된 병원균에 대한 엑스선의 살균 효과}

신선편의 채소류에 접종된 E. coli, L. monocytogenes, $S$. Typhimurium에 대하여 엑스선의 살균효과 측정 결과를 Fig. 1과 Table 2에 나타내었다. 당근에 접종된 E. coli의 접종 초기 균수는 $7.10 \log \mathrm{CFU} / \mathrm{g}$ 이었으나 $0.18 \mathrm{kGy}$ 의 흡수선량으로 엑스선 조사처리 시 $5.26 \mathrm{log} \mathrm{CFU} / \mathrm{g}$ 으로 약 $2 \log$ 수준이 감소되었다. 회귀방정식을 통해 초기균수 의 $90 \%(1 \log$ 수준)를 감소시키는데 필요한 흡수선량인 $\mathrm{D} 10$ 값은 $0.11 \mathrm{kGy}$ 로 산출되었다. L. monocytogenes와 $S$. Typhimurium의 접종 초기 균수는 각각 6.83 과 $6.94 \mathrm{log}$ $\mathrm{CFU} / \mathrm{g}$ 이었으나 $0.180 \mathrm{kGy}$ 의 흡수선량으로 엑스선 조사처 리 시 각각 5.84와 $6.05 \log \mathrm{CFU} / \mathrm{g}$ 으로 감소되었다. 따라서 당근에 접종된 L. monocytogenes와 $S$. Typhimurium의 D10 값은 모두 $0.20 \mathrm{kGy}$ 로 산출되었다. 또한 오이고추, 방울토 마토, 파프리카에 접종된 세균들의 $\mathrm{D}_{10}$ 값들은 $E . \mathrm{coli}$ 에 대 하여 0.13-0.21 kGy, L. monocytogenes에 대하여 0.21-0.26 $\mathrm{kGy}, S$. Typhimurium에 대하여 $0.20-0.32 \mathrm{kGy}$ 의 범위를 나 타내었다. Moosekian 등(14)은 시금치와 토마토에 접종된

Table 1. Viable cell count in fresh-cut vegetables irradiated with $\mathrm{X}$-rays at various doses

\begin{tabular}{|c|c|c|c|c|c|c|c|c|c|c|}
\hline \multirow[b]{2}{*}{ Sample } & \multirow{2}{*}{$\begin{array}{l}\text { Absorbed dose } \\
\text { (kGy) }\end{array}$} & \multicolumn{8}{|c|}{ Viable cells (log CFU/g) } & \multirow{2}{*}{$\begin{array}{l}\text { Bacterial } \\
\text { growth }\end{array}$} \\
\hline & & $\begin{array}{c}\text { Total aerobic } \\
\text { bacteria }\end{array}$ & $\begin{array}{c}\text { Yeast and } \\
\text { molds }\end{array}$ & Coliform group & $\begin{array}{c}\text { Escherichia } \\
\text { coli }\end{array}$ & $\begin{array}{l}\text { Salmonella } \\
\text { spp. }\end{array}$ & $\begin{array}{c}\text { Bacillus } \\
\text { cereus }\end{array}$ & $\begin{array}{c}\text { Staphylocuccus } \\
\text { aureus }\end{array}$ & $\begin{array}{l}\text { Clostridium } \\
\text { perffingens }\end{array}$ & \\
\hline \multirow{4}{*}{ Carrot } & 0.00 & $2.27 \pm 0.37$ & $\mathrm{ND}^{1)}$ & $1.15 \pm 0.15$ & $\mathrm{ND}$ & $\mathrm{ND}$ & $\mathrm{ND}$ & $\mathrm{ND}$ & $\mathrm{ND}$ & $+^{2)}$ \\
\hline & 0.20 & $1.00 \pm 0.00$ & $\mathrm{ND}$ & ND & $\mathrm{ND}$ & ND & $\mathrm{ND}$ & $\mathrm{ND}$ & $\mathrm{ND}$ & + \\
\hline & 0.40 & $\mathrm{ND}$ & $\mathrm{ND}$ & $\mathrm{ND}$ & $\mathrm{ND}$ & ND & $\mathrm{ND}$ & $\mathrm{ND}$ & $\mathrm{ND}$ & - \\
\hline & 0.60 & $\mathrm{ND}$ & $\mathrm{ND}$ & ND & $\mathrm{ND}$ & ND & $\mathrm{ND}$ & $\mathrm{ND}$ & $\mathrm{ND}$ & - \\
\hline \multirow{4}{*}{$\begin{array}{l}\text { Green } \\
\text { pepper }\end{array}$} & 0.00 & $3.34 \pm 0.23$ & $\mathrm{ND}$ & $2.68 \pm 0.10$ & $\mathrm{ND}$ & $\mathrm{ND}$ & $\mathrm{ND}$ & $\mathrm{ND}$ & ND & + \\
\hline & 0.20 & $1.45 \pm 0.45$ & $\mathrm{ND}$ & ND & $\mathrm{ND}$ & ND & $\mathrm{ND}$ & $\mathrm{ND}$ & $\mathrm{ND}$ & + \\
\hline & 0.40 & $\mathrm{ND}$ & $\mathrm{ND}$ & $\mathrm{ND}$ & $\mathrm{ND}$ & $\mathrm{ND}$ & $\mathrm{ND}$ & $\mathrm{ND}$ & $\mathrm{ND}$ & - \\
\hline & 0.60 & $\mathrm{ND}$ & $\mathrm{ND}$ & ND & $\mathrm{ND}$ & ND & $\mathrm{ND}$ & $\mathrm{ND}$ & ND & - \\
\hline \multirow{4}{*}{$\begin{array}{l}\text { Cherry } \\
\text { tomato }\end{array}$} & 0.00 & $\mathrm{ND}$ & $\mathrm{ND}$ & $\mathrm{ND}$ & $\mathrm{ND}$ & ND & $\mathrm{ND}$ & $\mathrm{ND}$ & $\mathrm{ND}$ & + \\
\hline & 0.20 & $\mathrm{ND}$ & $\mathrm{ND}$ & $\mathrm{ND}$ & $\mathrm{ND}$ & ND & $\mathrm{ND}$ & $\mathrm{ND}$ & ND & - \\
\hline & 0.40 & $\mathrm{ND}$ & $\mathrm{ND}$ & ND & $\mathrm{ND}$ & ND & $\mathrm{ND}$ & $\mathrm{ND}$ & $\mathrm{ND}$ & - \\
\hline & 0.60 & $\mathrm{ND}$ & $\mathrm{ND}$ & $\mathrm{ND}$ & $\mathrm{ND}$ & ND & $\mathrm{ND}$ & $\mathrm{ND}$ & $\mathrm{ND}$ & - \\
\hline \multirow{4}{*}{ Paprika } & 0.00 & $1.63 \pm 0.33$ & $\mathrm{ND}$ & $1.15 \pm 0.15$ & $\mathrm{ND}$ & ND & $\mathrm{ND}$ & $\mathrm{ND}$ & $\mathrm{ND}$ & + \\
\hline & 0.20 & $\mathrm{ND}$ & $\mathrm{ND}$ & ND & $\mathrm{ND}$ & ND & $\mathrm{ND}$ & $\mathrm{ND}$ & ND & - \\
\hline & 0.40 & $\mathrm{ND}$ & $\mathrm{ND}$ & ND & $\mathrm{ND}$ & ND & $\mathrm{ND}$ & $\mathrm{ND}$ & $\mathrm{ND}$ & - \\
\hline & 0.60 & ND & ND & ND & ND & ND & ND & ND & ND & - \\
\hline
\end{tabular}

${ }^{1)}$ Not detected within the detection limit $<1 \log \mathrm{CFU} / \mathrm{g}$

${ }^{2}$ Bacterial growth was observed through color change of thioglycollate medium after incubation at $37^{\circ} \mathrm{C}$ for $48 \mathrm{~h}$ (positive) 
(A) Carrot

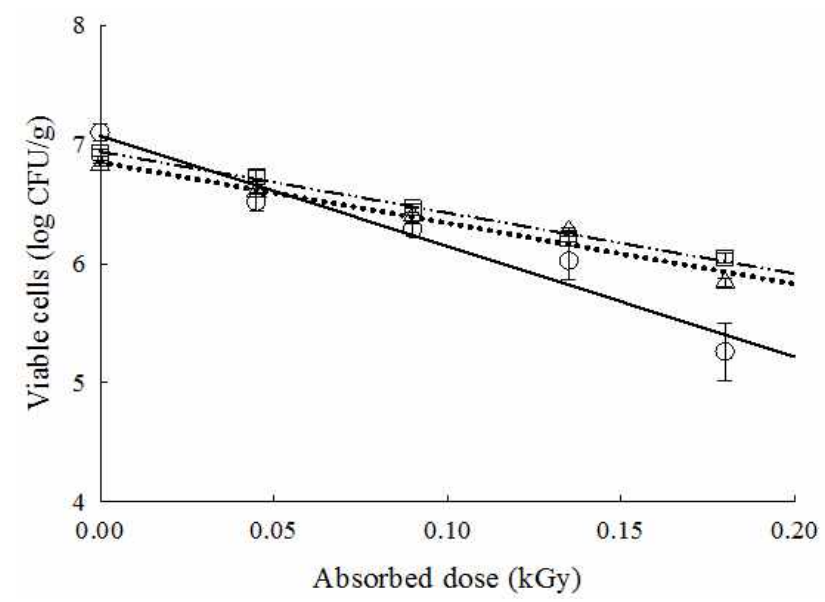

(C) Cherry tomato

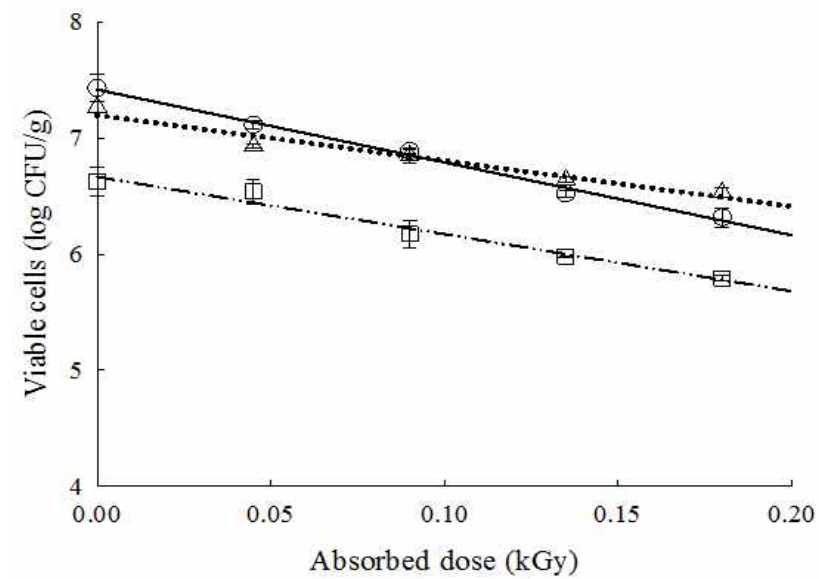

(B) Green pepper

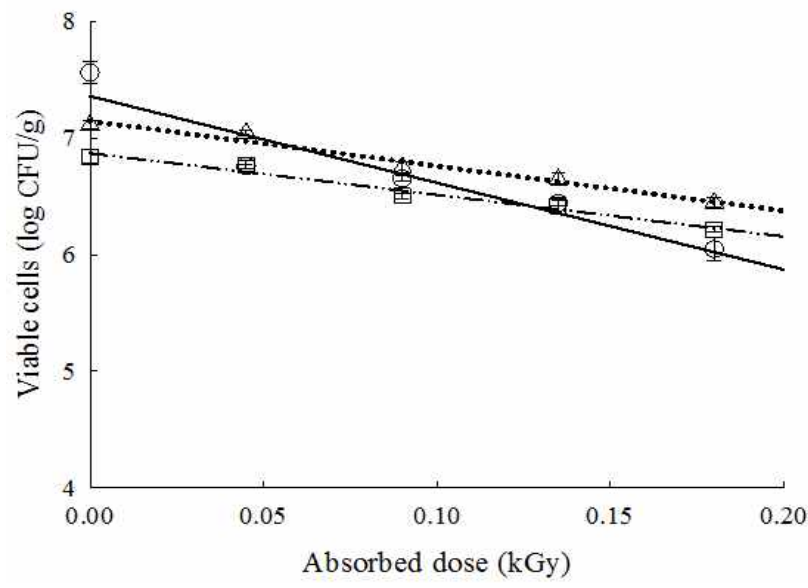

(D) Paprika

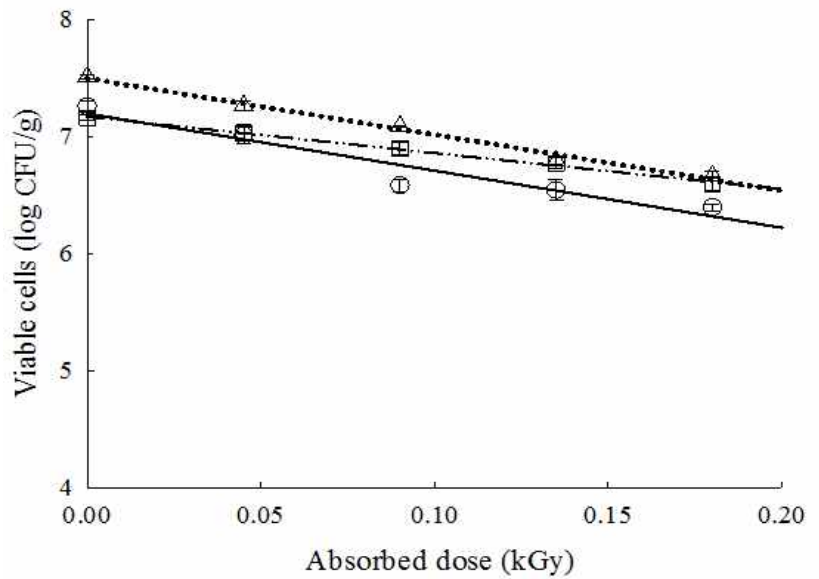

Fig. 1. Viability of bacterial pathogens inoculated on fresh-cut vegetables following X-ray irradiation at different doses.

$\bigcirc$, Escherichia coli, $\triangle$, Listeria monocytogenes, $\square$, Salmonella Typhimurium.

Table 2. D10-values of X-ray irradiation for various pathogens inoculated on fresh-cut vegetables

\begin{tabular}{ccccc}
\hline Sample & Microorganism & Regression equation & $\mathrm{R}^{2}$ & D10-value \\
\hline Carrot & Escherichia coli & $\mathrm{Y}=-9.29 \mathrm{X}+7.07$ & 0.92 & 0.11 \\
& Listeria monocytogenes & $\mathrm{Y}=-5.10 \mathrm{X}+6.85$ & 0.95 & 0.20 \\
& Salmonella Typhimurium & $\mathrm{Y}=-5.11 \mathrm{X}+6.94$ & 0.98 & 0.20 \\
\hline \multirow{2}{*}{ Cucumber pepper } & Escherichia coli & $\mathrm{Y}=-7.43 \mathrm{X}+7.36$ & 0.89 & 0.13 \\
& Listeria monocytogenes & $\mathrm{Y}=-3.85 \mathrm{X}+7.14$ & 0.95 & 0.26 \\
& Salmonella Typhimurium & $\mathrm{Y}=-3.57 \mathrm{X}+6.87$ & 0.94 & 0.28 \\
\hline \multirow{2}{*}{ Cherry tomato } & Escherichia coli & $\mathrm{Y}=-6.27 \mathrm{X}+7.41$ & 0.97 & 0.16 \\
& Listeria monocytogenes & $\mathrm{Y}=-3.92 \mathrm{X}+7.19$ & 0.94 & 0.26 \\
& Salmonella Typhimurium & $\mathrm{Y}=-4.93 \mathrm{X}+6.66$ & 0.92 & 0.20 \\
\hline Paprika & Escherichia coli & $\mathrm{Y}=-4.87 \mathrm{X}+7.19$ & 0.89 & 0.21 \\
& Listeria monocytogenes & $\mathrm{Y}=-4.80 \mathrm{X}+7.50$ & 0.98 & 0.21 \\
& Salmonella Typhimurium & $\mathrm{Y}=-3.09 \mathrm{X}+7.17$ & 0.95 & 0.32 \\
\hline
\end{tabular}


E. coli O157:H7 및 L. monocytogenes, S. enterica에 대한 엑스선의 $\mathrm{D}_{10}$ 값이 각각 $0.39-1.10,0.66-1.00,0.56-1.20 \mathrm{kGy}$ 의 범위를 나타낸다고 보고한 바 있어 본 실험의 결과 보다 높은 $\mathrm{D}_{10}$ 값을 나타내었다. 그러나 이는 접종실험에 사용된 균주의 차이와 시료의 차이에 의해 기인하는 것으로 사료된 다.

식품공전에서 신선편의 식품의 미생물 기준은 $E$ coli가 $10 \mathrm{CFU} / \mathrm{g}, S$. aureus와 C. perfringens 가 $100 \mathrm{CFU} / \mathrm{g}$, B. cereus 가 $1,000 \mathrm{CFU} / \mathrm{g}$ 이하이며, Salmonella spp.는 음성이여야 한다고 명시하고 있다. 본 실험을 통해 확인된 신선편의 채소류의 미생물 오염수준은 식품공전의 미생물 규격을 충족시키고 있지만, 본 연구의 목표는 면역력이 저하된 방 사선 암치료 환자 또는 백혈병 환자에게 미생물학적으로 안전한 신선편의 채소류를 제 공하는 것이기 때문에 멸균 처리가 필요하다. 이러한 관점에서 $0.4 \mathrm{kGy}$ 의 흡수선량은 신선편의 채소류의 멸균을 위한 최소 흡수선량으로 판단된 다. 즉, 신선편의 채소류의 초기 미생물 오염도가 $1 \log$ 의 검출한계 이하의 수준이고 접종실험을 통한 세균의 $\mathrm{D}_{10}$ 값 이 최대 $0.4 \mathrm{kGy}$ 이하이므로 신선편의 채소류의 미생물학 적 안전성을 위한 잠정적인 최소 멸균선량으로 $0.4 \mathrm{kGy}$ 를 설정하였다.

신선편의 채소류의 이화학적, 관능적 품질 평가

다양한 흡수선량으로 엑스선 조사처리한 신선편의 채소
류의 이화학적 품질 평가 결과를 Table 3에 나타내었다. 당근의 경우 $\mathrm{pH}$ 를 제외한 모든 항목에 있어 비조사구와 조사처리구 사이에서의 유의적인 차이는 없었다. 그러나 흡수선량별 유의적인 차이를 나타낸 $\mathrm{pH}$ 의 경우 흡수선량 의 증가에 따른 비례적인 변화가 아니므로 엑스선 조사처리 에 따른 영향 보다는 시료 개체 마다의 차이 때문인 것으로 사료된다. 오이고추의 경우 $\mathrm{pH}$, 적정산도 및 색도에서 유의 적인 차이는 없었으며, $0.6 \mathrm{kGy}$ 조사처리구에서 비조사구 와 대조하여 경도가 다소 낮아졌으나 유의적인 차이가 없는 것으로 나타났다. 방울토마토의 경우 경도에서 $0.6 \mathrm{kGy}$ 의 흡수선량으로 조사처리 하였을 때 비조사구와 대조하여 유의적인 차이가 나타났으며, $0.6 \mathrm{kGy}$ 조사처리구의 경도 는 다른 실험구들에 비해 유의적으로 낮은 경도를 나타내었 다( $\mathrm{p}<0.05)$. 파프리카의 경우 경도만이 유의적인 차이를 나 타내었으며, $0.2 \mathrm{kGy}$ 이상의 흡수선량으로 조사처리 시 흡 수선량 증가에 따라 비례적으로 경도가 감소하였다 $(\mathrm{p}<0.05)$. 종합적으로 신선편의 채소류의 경도만이 흡수선 량의 증가에 따라 비례적으로 유의적인 차이를 나타내었으 며, 파프리카를 제외하고 $0.4 \mathrm{kGy}$ 이하의 흡수선량으로 엑 스선 조사처리된 시료들의 경도는 비조사구와 유의차가 없는 것으로 판단하였다. 이러한 채소류의 경도 감소는 품 목별로 세포의 구조 및 성분 조성에 따라 차이가 있으며, 세포벽을 구성하는 hemicellulose와 pectin 등이 방사선의 이온화 작용으로 분해되는 현상으로부터 기인하는 것으로

Table 3. Physicochemical characteristics of fresh-cut vegetables irradiated with X-rays at various doses

\begin{tabular}{|c|c|c|c|c|c|c|c|}
\hline \multirow{2}{*}{ Sample } & \multirow{2}{*}{$\begin{array}{l}\text { Absorbed dose } \\
\quad(\mathrm{kGy})\end{array}$} & \multirow{2}{*}{$\mathrm{pH}$} & \multirow{2}{*}{ Acidity (\%) } & \multicolumn{3}{|c|}{ Color } & \multirow{2}{*}{ Firmness $(\mathrm{N})$} \\
\hline & & & & $\mathrm{L}^{*}$ & $a^{*}$ & $b^{*}$ & \\
\hline \multirow{4}{*}{ Carrot } & 0.00 & $6.48 \pm 0.08^{1) b 2}$ & $0.06 \pm 0.01^{\text {NS3) }}$ & $59.30 \pm 2.71^{\mathrm{NS}}$ & $36.93 \pm 1.93^{\mathrm{NS}}$ & $40.99 \pm 2.76^{\mathrm{NS}}$ & $7,032 \pm 310^{\mathrm{NS}}$ \\
\hline & 0.20 & $6.52 \pm 0.08^{\mathrm{ab}}$ & $0.05 \pm 0.01$ & $59.35 \pm 2.61$ & $37.85 \pm 2.12$ & $41.46 \pm 3.02$ & $6,957 \pm 409$ \\
\hline & 0.40 & $6.42 \pm 0.08^{b}$ & $0.06 \pm 0.01$ & $58.08 \pm 1.05$ & $36.70 \pm 1.89$ & $40.92 \pm 2.65$ & $6,854 \pm 561$ \\
\hline & 0.60 & $6.58 \pm 0.04^{\mathrm{a}}$ & $0.06 \pm 0.01$ & $58.33 \pm 0.83$ & $37.65 \pm 1.77$ & $41.81 \pm 2.97$ & $6,736 \pm 400$ \\
\hline \multirow{4}{*}{ Green pepper } & 0.00 & $6.55 \pm 0.08^{\mathrm{NS}}$ & $0.05 \pm 0.01^{\mathrm{NS}}$ & $40.85 \pm 2.32^{\mathrm{NS}}$ & $-9.10 \pm 0.70^{\mathrm{NS}}$ & $22.15 \pm 2.77^{\mathrm{NS}}$ & $3,849 \pm 376^{\mathrm{NS}}$ \\
\hline & 0.20 & $6.52 \pm 0.08$ & $0.06 \pm 0.01$ & $40.88 \pm 1.69$ & $-9.06 \pm 0.80$ & $22.54 \pm 3.07$ & $3,780 \pm 313$ \\
\hline & 0.40 & $6.48 \pm 0.08$ & $0.06 \pm 0.01$ & $40.07 \pm 1.81$ & $-9.08 \pm 0.63$ & $22.48 \pm 2.26$ & $3,714 \pm 393$ \\
\hline & 0.60 & $6.55 \pm 0.05$ & $0.05 \pm 0.01$ & $39.56 \pm 2.74$ & $-9.10 \pm 0.82$ & $22.18 \pm 2.67$ & $3,620 \pm 359$ \\
\hline \multirow{4}{*}{ Cherry tomato } & 0.00 & $4.72 \pm 0.04^{\mathrm{NS}}$ & $0.37 \pm 0.02^{\mathrm{NS}}$ & $33.68 \pm 1.43^{\mathrm{NS}}$ & $18.06 \pm 1.43^{\mathrm{NS}}$ & $17.11 \pm 2.64^{\mathrm{NS}}$ & $1,637 \pm 132^{\mathrm{a}}$ \\
\hline & 0.20 & $4.70 \pm 0.03$ & $0.38 \pm 0.01$ & $33.39 \pm 0.52$ & $18.36 \pm 2.08$ & $15.89 \pm 1.00$ & $1,557 \pm 191^{\mathrm{a}}$ \\
\hline & 0.40 & $4.73 \pm 0.05$ & $0.38 \pm 0.03$ & $32.93 \pm 0.51$ & $18.86 \pm 2.16$ & $15.90 \pm 1.43$ & $1,537 \pm 148^{\mathrm{a}}$ \\
\hline & 0.60 & $4.75 \pm 0.05$ & $0.38 \pm 0.01$ & $33.10 \pm 0.59$ & $18.77 \pm 1.70$ & $15.78 \pm 1.30$ & $1,353 \pm 106^{b}$ \\
\hline \multirow{4}{*}{ Paprika } & 0.00 & $5.25 \pm 0.05^{\mathrm{NS}}$ & $0.18 \pm 0.01^{\mathrm{NS}}$ & $35.16 \pm 1.28^{\mathrm{NS}}$ & $-27.90 \pm 3.60^{\mathrm{NS}}$ & $15.24 \pm 2.07^{\mathrm{NS}}$ & $2,728 \pm 105^{\mathrm{a}}$ \\
\hline & 0.20 & $5.25 \pm 0.05$ & $0.18 \pm 0.01$ & $35.51 \pm 2.08$ & $-26.52 \pm 3.84$ & $16.47 \pm 2.54$ & $2,553 \pm 130^{b}$ \\
\hline & 0.40 & $5.27 \pm 0.08$ & $0.17 \pm 0.01$ & $35.14 \pm 2.44$ & $-27.68 \pm 3.70$ & $16.75 \pm 2.11$ & $2,411 \pm 107^{\mathrm{c}}$ \\
\hline & 0.60 & $5.27 \pm 0.08$ & $0.17 \pm 0.01$ & $34.14 \pm 1.83$ & $-26.29 \pm 1.99$ & $15.96 \pm 3.33$ & $2,375 \pm 117^{\mathrm{c}}$ \\
\hline
\end{tabular}

\footnotetext{
${ }^{1)}$ Mean value \pm SD $(\mathrm{n}=6)$.

2)a-c Mean values within a row follow by the different letter are significantly different $(p<0.05)$.
}

${ }^{3) \text { NS }}$ No significant within a column for each sample with a $95 \%$ confidence level $(p<0.05)$. 
판단된다 $(15,16)$.

다양한 흡수선량으로 엑스선 조사처리한 신선편의 채소 류의 관능적 품질 평가 결과를 Table 4에 나타내었다. 공통 적으로 외관에 대한 선호도와 이취에 대한 특성강도에 있어 시료간 유의적인 차이는 없었으며, 풍미, 조직감, 맛에 대한 선호도는 품목에 따라 상이한 결과들이 도출되었다. 각각 의 관능적 품질 특성치를 고려하여 평가된 전체 선호도의 경우 흡수선량의 증가에 따라 낮아지는 경향을 나타내었으 나, 방울토마토에 있어 시료간 유의차는 없었다 $(\mathrm{p}<0.05)$. 당근과 오이고추의 경우 $0.4 \mathrm{kGy}$ 이상의 흡수선량으로 조 사처리 시 비조사구에 비해 유의적인 낮은 전체 선호도를 나타내었으며, 파프리카는 $0.2 \mathrm{kGy}$ 이상의 흡수선량에서 유의적이 차이가 있음이 인지되었다 $(\mathrm{p}<0.05)$. 그러나 평가 된 모든 신선편의 채소류의 전체 선호도는 7점 척도에서 5.0 점 이상으로 나타나 최대 $0.6 \mathrm{kGy}$ 의 흡수선량으로 엑스 선 조사처리된 시료 모두 관능적 품질이 수용 가능한 수준 (보통 4점) 이상인 것으로 사료된다.

\section{엑스선 멸균 처리된 신선편의 채소류에 대한 선호도 조사}

동남권원자력의학원에 입원 중인 암환자 50 명을 대상으 로 $0.4 \mathrm{kGy}$ 의 흡수선량에서 엑스선 멸균 처리된 신선편의 채소류에 대하여 선호도 조사를 실시하였다(Table 5). 당근 의 경우 색상은 '매우 좋다’ 13 명(26\%), ‘좋다' 21 명(42\%),
‘보통이다' 15 명(30\%), ‘매우 나쁘다' 1 명(2\%)으로 3.90점 이었고 풍미는 '매우 좋다' 12 명 (24\%) '좋다' 21 명(42\%), '보통이다' 16 명 $(32 \%)$, ‘매우 나쁘다' 1 명(2\%)으로 3.86점 이었으며, 조직감은 '매우 좋다' 12 명 $(24 \%)$, '좋다' 26 명 (52\%), '보통이다' 11 명 $(22 \%)$, '나쁘다' 1 명 $(2 \%)$ 으로 3.98 점이었다. 맛은 '매우 좋다' 12 명 (24\%), '좋다' 25 명 $(50 \%)$, '보통이다' 13 명 $(26 \%)$ 으로 3.98 점이었고 전반적인 만족도 는 '매우 좋다' 12 명(24\%), '좋다' 27 명(54\%), '보통이다' 11 명 $22 \%$ 으로 4.02 점이었다. 당근의 선호도 점수는 평균 3.93점으로 신선편의 채소류 중 가장 낮은 점수를 보였는 데, 이는 당근에 대한 개인적인 기호도가 반영된 것으로 사료된다. 오이고추와 방울토마토의 경우 모든 항목에 대 한 평균 선호도 점수가 5점 척도에서 각각 $4.14,4.21$ 점이었 으며, 모든 항목에서 $80 \%$ 이상의 응답자가 '좋다'와 '매우 좋다’를 답하였다. 특히 방울토마토의 평균 선호도 점수는 4.21점으로 시식 제품 중에서 가장 높은 점수를 나타내었으 며, 파프리카는 평균 4.10 점의 평균 선호도 점수를 나타내 었으나 맛에 대한 선호도 점수가 3.70으로 비교적 낮았다. 이는 소스나 드레싱이 없고 아무런 가미가 되지 않은 상태 로 시식한 결과이며 본 연구의 제한점이라 사료된다. 이러 한 결과들을 토대로 오이고추, 방울토마토, 파프리카는 면 역력이 저하된 환자들을 위하여 위생학적으로 안전한 신선 편의 채소로 제공이 가능할 것으로 판단된다.

Table 4. Organoleptic evaluation of fresh-cut vegetables irradiated with X-rays at various doses

\begin{tabular}{|c|c|c|c|c|c|c|c|}
\hline \multirow{2}{*}{ Sample } & \multirow{2}{*}{$\begin{array}{l}\text { Absorbed dose } \\
\quad(\mathrm{kGy})\end{array}$} & \multicolumn{6}{|c|}{ Attributes } \\
\hline & & Appearance & Flavor & Texture & Taste & Off-flavor & Overall acceptance \\
\hline \multirow{4}{*}{ Carrot } & 0.00 & $6.5 \pm 0.5^{1) \mathrm{NS} 2)}$ & $6.0 \pm 0.8^{\mathrm{NS}}$ & $6.5 \pm 0.8^{\mathrm{a} 3)}$ & $6.3 \pm 0.5^{\mathrm{NS}}$ & $1.0 \pm 0.0^{\mathrm{NS}}$ & $6.5 \pm 0.5^{\mathrm{a}}$ \\
\hline & 0.20 & $6.3 \pm 0.5$ & $5.9 \pm 0.6$ & $6.1 \pm 0.8^{\mathrm{ab}}$ & $6.0 \pm 0.5$ & $1.0 \pm 0.0$ & $6.1 \pm 0.6^{\mathrm{ab}}$ \\
\hline & 0.40 & $6.4 \pm 0.5$ & $6.0 \pm 0.8$ & $5.6 \pm 0.5^{b}$ & $5.8 \pm 0.9$ & $1.0 \pm 0.0$ & $5.6 \pm 0.9^{b}$ \\
\hline & 0.60 & $6.4 \pm 0.5$ & $6.0 \pm 0.8$ & $5.6 \pm 0.7^{\mathrm{b}}$ & $5.5 \pm 0.8$ & $1.1 \pm 0.4$ & $5.6 \pm 0.7^{b}$ \\
\hline \multirow{4}{*}{ Green pepper } & 0.00 & $6.9 \pm 0.4^{\mathrm{NS}}$ & $6.8 \pm 0.5^{\mathrm{a}}$ & $6.8 \pm 0.5^{\mathrm{a}}$ & $6.8 \pm 0.5^{\mathrm{a}}$ & $1.0 \pm 0.1^{\mathrm{NS}}$ & $6.8 \pm 0.5^{\mathrm{a}}$ \\
\hline & 0.20 & $6.9 \pm 0.4$ & $6.3 \pm 0.7^{\mathrm{ab}}$ & $6.3 \pm 0.5^{\mathrm{ab}}$ & $6.1 \pm 0.4^{b}$ & $1.0 \pm 0.1$ & $6.4 \pm 0.5^{\mathrm{ab}}$ \\
\hline & 0.40 & $6.9 \pm 0.4$ & $6.0 \pm 0.8^{\mathrm{b}}$ & $5.9 \pm 0.6^{b}$ & $5.9 \pm 0.6^{b}$ & $1.0 \pm 0.1$ & $5.9 \pm 0.6^{b}$ \\
\hline & 0.60 & $6.8 \pm 0.5$ & $6.1 \pm 0.6^{\mathrm{ab}}$ & $5.8 \pm 0.7^{\mathrm{b}}$ & $5.6 \pm 0.7^{b}$ & $1.0 \pm 0.1$ & $5.8 \pm 0.7^{\mathrm{b}}$ \\
\hline \multirow{4}{*}{ Cherry tomato } & 0.00 & $7.0 \pm 0.1^{\mathrm{NS}}$ & $6.8 \pm 0.5^{\mathrm{a}}$ & $6.8 \pm 0.5^{\mathrm{NS}}$ & $6.8 \pm 0.5^{\mathrm{NS}}$ & $1.0 \pm 0.1^{\mathrm{NS}}$ & $6.8 \pm 0.5^{\mathrm{NS}}$ \\
\hline & 0.20 & $7.0 \pm 0.1$ & $6.3 \pm 0.5^{b}$ & $6.4 \pm 0.5$ & $6.3 \pm 0.5$ & $1.0 \pm 0.1$ & $6.3 \pm 0.5$ \\
\hline & 0.40 & $7.0 \pm 0.1$ & $6.4 \pm 0.5^{\mathrm{ab}}$ & $6.3 \pm 0.5$ & $6.4 \pm 0.5$ & $1.0 \pm 0.1$ & $6.3 \pm 0.5$ \\
\hline & 0.60 & $7.0 \pm 0.1$ & $6.1 \pm 0.4^{b}$ & $6.1 \pm 0.8$ & $6.3 \pm 0.5$ & $1.0 \pm 0.1$ & $6.3 \pm 0.5$ \\
\hline \multirow{4}{*}{ Paprika } & 0.00 & $6.6 \pm 0.5^{\mathrm{NS}}$ & $6.5 \pm 0.5^{\mathrm{a}}$ & $6.6 \pm 0.5^{\mathrm{a}}$ & $6.5 \pm 0.5^{\mathrm{a}}$ & $1.0 \pm 0.1^{\mathrm{NS}}$ & $6.5 \pm 0.5^{\mathrm{a}}$ \\
\hline & 0.20 & $6.6 \pm 0.5$ & $5.9 \pm 0.6^{b}$ & $6.1 \pm 0.4^{\mathrm{ab}}$ & $5.6 \pm 0.5^{\mathrm{b}}$ & $1.0 \pm 0.1$ & $5.8 \pm 0.5^{\mathrm{b}}$ \\
\hline & 0.40 & $6.6 \pm 0.5$ & $5.9 \pm 0.6^{\mathrm{ab}}$ & $5.9 \pm 0.6^{b}$ & $5.8 \pm 0.5^{\mathrm{b}}$ & $1.0 \pm 0.1$ & $5.6 \pm 0.5^{\mathrm{b}}$ \\
\hline & 0.60 & $6.6 \pm 0.5$ & $5.8 \pm 0.7^{\mathrm{b}}$ & $5.5 \pm 0.8^{\mathrm{b}}$ & $5.5 \pm 0.8^{\mathrm{b}}$ & $1.0 \pm 0.1$ & $5.5 \pm 0.8^{\mathrm{b}}$ \\
\hline
\end{tabular}

\footnotetext{
${ }^{1)}$ Mean value \pm SD $(\mathrm{n}=8)$.

${ }^{2) \mathrm{NS}}$ No significant within a column for each sample with a $95 \%$ confidence level $(\mathrm{p}<0.05)$.

${ }^{3) a-b}$ Mean values within a row follow by the different letter are significantly different $(\mathrm{p}<0.05)$.
} 
Table 5. Preference survey on fresh-cut vegetables sterilized by X-ray irradiation at $0.40 \mathrm{kGy}$

\begin{tabular}{|c|c|c|c|c|c|c|c|}
\hline \multirow{2}{*}{ Sample } & \multirow{2}{*}{ Attribute } & \multicolumn{5}{|c|}{ No. of respondents (proportion to the total respondents, $\mathrm{n}=50$ ) } & \multirow{2}{*}{ Score } \\
\hline & & Very bad & $\mathrm{Bad}$ & Normal & Good & Very Good & \\
\hline \multirow{6}{*}{ Carrot } & Color & $1(2 \%)$ & & $15(30 \%)$ & $21(42 \%)$ & $13(26 \%)$ & $3.90 \pm 0.86$ \\
\hline & Flavor & $1(2 \%)$ & & $16(32 \%)$ & $21(42 \%)$ & $12(24 \%)$ & $3.86 \pm 0.86$ \\
\hline & Texture & & $1(2 \%)$ & $11(22 \%)$ & $26(52 \%)$ & $12(24 \%)$ & $3.98 \pm 0.74$ \\
\hline & Taste & & & $13(26 \%)$ & $25(50 \%)$ & $12(24 \%)$ & $3.98 \pm 0.71$ \\
\hline & Overall acceptance & & & $11(22 \%)$ & $27(54 \%)$ & $12(24 \%)$ & $4.02 \pm 0.68$ \\
\hline & Average & & & & & & 3.94 \\
\hline \multirow{6}{*}{ Green pepper } & Color & & & $5(10 \%)$ & $26(52 \%)$ & $19(38 \%)$ & $4.28 \pm 0.64$ \\
\hline & Flavor & & $1(2 \%)$ & $12(24 \%)$ & $24(48 \%)$ & $13(26 \%)$ & $3.98 \pm 0.77$ \\
\hline & Texture & & & $8(16 \%)$ & $27(54 \%)$ & $15(30 \%)$ & $4.14 \pm 0.67$ \\
\hline & Taste & & & $9(18 \%)$ & $25(50 \%)$ & $16(32 \%)$ & $4.14 \pm 0.70$ \\
\hline & Overall acceptance & & & $7(14 \%)$ & $29(58 \%)$ & $14(28 \%)$ & $4.14 \pm 0.64$ \\
\hline & Average & & & & & & 4.14 \\
\hline \multirow{6}{*}{ Cherry tomato } & Color & & & $4(8 \%)$ & $28(56 \%)$ & $18(36 \%)$ & $4.28 \pm 0.61$ \\
\hline & Flavor & & & $9(18 \%)$ & $24(48 \%)$ & $17(34 \%)$ & $4.16 \pm 0.71$ \\
\hline & Texture & & & $9(18 \%)$ & $24(48 \%)$ & $17(34 \%)$ & $4.16 \pm 0.71$ \\
\hline & Taste & & & $5(10 \%)$ & $28(56 \%)$ & $17(34 \%)$ & $4.24 \pm 0.62$ \\
\hline & Overall acceptance & & & $7(14 \%)$ & $25(50 \%)$ & $18(36 \%)$ & $4.22 \pm 0.68$ \\
\hline & Average & & & & & & 4.21 \\
\hline \multirow{6}{*}{ Paprika } & Color & $1(2 \%)$ & & $4(8 \%)$ & $26(52 \%)$ & $19(38 \%)$ & $4.24 \pm 0.77$ \\
\hline & Flavor & & & $7(14 \%)$ & $24(48 \%)$ & $19(38 \%)$ & $4.24 \pm 0.69$ \\
\hline & Texture & & & $7(14 \%)$ & $28(56 \%)$ & $15(30 \%)$ & $4.16 \pm 0.65$ \\
\hline & Taste & $1(2 \%)$ & $2(4 \%)$ & $17(24 \%)$ & $21(42 \%)$ & $9(18 \%)$ & $3.70 \pm 0.88$ \\
\hline & Overall acceptance & & & $8(16 \%)$ & $27(54 \%)$ & $15(30 \%)$ & $4.14 \pm 0.67$ \\
\hline & Average & & & & & & 4.10 \\
\hline
\end{tabular}

\section{요 약}

본 연구는 면역저하 환자용 신선편의 채소류의 위생화를 위해 당근, 오이고추, 방울토마토, 파프리카를 모델식품으 로 선정하여 다양한 흡수선량으로 엑스선 조사처리한 후 미생물학적, 이화학적, 관능적 품질 평가를 수행하였다. 당 근과 오이고추의 경우 $0.4 \mathrm{kGy}$, 방울토마토와 파프리카의 경우 $0.2 \mathrm{kGy}$ 이상의 흡수선량으로 엑스선 조사처리 시 멸균이 확인되었으며, 총 호기성세균 및 대장균군을 제외 한 병원균들은 $1 \log$ 수준의 검출한계 이하로 나타났다. 모델식품에 접종된 E. coli. L monocytogenes, $S$. Typhimyrium 에 대한 엑스선의 D10값은 0.11-0.32 kGy로 나타나, 0.4 $\mathrm{kGy}$ 의 흡수선량을 신선편의 채소류의 멸균을 위한 잠정적 인 최소 흡수선량으로 설정하였다. 최대 $0.6 \mathrm{kGy}$ 의 흡수선 량으로 엑스선 조사처리된 신선편의 채소류에 대한 전체 선호도의 경우 7점 척도에서 모두 5.0 점 이상으로 나타나 이들의 관능적 품질이 수용 가능한 수준인 것으로 판단하였
다. 또한, 암환자를 대상으로 엑스선 멸균처리(0.4 kGy)된 신선편의 채소류에 대한 선호도 설문조사에서 오이고추와 방울토마토, 파프리카의 경우 모든 항목에 대한 평균 선호 도 점수는 5점 척도에서 모두 4.0점 이상으로 나타났다. 따라서 엑스선으로 멸균처리된 오이고추, 방울토마토, 파 프리카는 면역력이 저하된 환자들을 위한 위생학적으로 안전한 신선편의 채소로 제공이 가능할 것으로 판단된다.

\section{감사의 글}

본 연구는 2016년 정부(미래창조과학부)의 재원으로 한 국연구재단의 지원을 통해 수행되었으며(2012M2A2A6011320), 그 지원에 감사드립니다.

\section{References}

1. Ministry Health \& Welfare, National Cancer Center 
(2012) National cancer registration and statistics in 2010 (http://www.cancer.go.kr/ncic/cics_g/cics_g02/cics_g02 7/1653504_6065.html) (accessed on 18 December 2012)

2. Ministry Health \& Welfare, National Cancer Center (2012) Cancer facts \& figures 2012 (http://www.cancer. go.kr/ncic/cics_g/cics_g02/cics_g027/1649336_6065.ht $\mathrm{ml}$ ) (accessed on 18 December 2012)

3. Jang SR, Kim HS, Lee YH (1999) Nutritional assessment and dietary management during anti-cancer chemotherapy in pediatric oncology patients. Korean $\mathbf{J}$ Pediatr Gastroenterol Nutr, 2, 204-210

4. Lee BS, Park KH, Cho JH (2011) A study on the effect of selection attributes on consumer satisfaction and repurchase intention about HMR-In case of ready-toend-cook-. Korean J Culinary Res, 50, 85-97

5. Kwak DK, Lee KE, Park HW, Ryu K, Choi EJ, Hong WS, Jang HJ, Kim SH (1997) The survey of housewives' perception for the development of refrigerated convenience foods for Koreans. Korean J Dietary Culture, 12, 391-400

6. Smith, DW, Barlow CK, Alderton L, Jacobson MF (2011) Outbreak alert! Center for Science in the Public Interest. Available at:http://www.cspint.org/reports/outbeak_report. pdf (accessed on August 15.)

7. Beuchat LR (1996) Pathogenic microorganisms associated with fresh produce. J Food Prot, 59, 204-216

8. Gleeson E, O'Beirne D (2005) Effects of process severity on survival and growth of Escherichia coli and Listeria innocua on minimally processed vegetables. Food Control
16, 677-685

9. Byun MW, Lee JW (2003) Application of irradiation technology for food safety and security. Food Science and Industry, 36, 25-41

10. Lee YS, Oh SH, Lee JW, Kim JH, Kim DS, Byun MW (2003) Effects of gamma irradiation on physicochemical and textural properties of starches. Food Sci Biotechnol, $12,508-512$

11. Thayer DW (1990) Food irradiation, benefits, and concerns. J Food Qual, 13, 147-169

12. Song BS, Lee YJ, Moon BG, Go SM, Park JH, Kim JK, Jung K, Kim DH, Ryu SR (2016) Comparison of bactericidal efficiency of $7.5 \mathrm{MeV}$ X-rays, gamma-rays, and $10 \mathrm{MeV}$ e-beams. Radiat Phys Chem, 125, 106-108

13. Miller RB (2003) Food irradiation using bremsstrahlung X-rays. Radiat Phys Chem, 68, 963-974

14. Moosekian SR, Jeong SH, Marks BP, Ryser ET (2012) $\mathrm{X}$-ray irradiation as a microbial intervention strategy for food. Annu Rev Food Sci Technol, 3, 493-510

15. Nayak CA, Suguma K, Narasimhamurthy K, Rastogi NK (2007) Effect of gamma irradiation on histological and textural properties if carrot, potato and beetroot. J Food Eng, 79, 765-770

16. Prakash A, Manley J, Decosta S, Caporaso F, Foley D (2002) The effects of gamma irradiation on the microbiological, physical and sensory qualities of diced tomatoes. Radia Phys Chem, 63, 387-390 